\title{
The Comparison of Curricular in Fashion Field between Korean and American Universities
}

\author{
Kim, Sun Hwa \\ Professor, Department of Fashion Design, Sunchon National University \\ 한·미 4년제 대학의 패션관련학과 교과과정 비교분석 연구 \\ 김 선 화 \\ 순천대학교 패션디자인학과 교수
}

\begin{abstract}
The objective of the study was to compare the curricular in fashion field between Korean and American universities. Initially, curricular data of Korean universities were collected through the internet, telephone calls and e-mails from March to May, 2006. The data was then modified in August, 2009. Data from American universities were only collected through the internet from January to March, 2009. The name of the department, total credits opened, credits opened for each area and so on, were analyzed using descriptive statistics. There were 20 national universities and 61 private universities with fashion related departments in Korea, while 87 public universities and 21 private universities in the USA. The name of 'Fashion Design' in the departments was prevalent in 40 universities in Korea. On the contrary, 'Fashion Marketing' was the most dominant name in 31 universities in the USA. Ninety percent of the universities in Korea opened over eighty to ninety total credits, but $83 \%$ of American universities opened under eighty to ninety total credits. Most universities in Korea opened many credits for construction, design/ aesthetics, marketing and textile areas more than those in the USA.
\end{abstract}

Key words: curricular, fashion field, Korean universities, American universities

\section{Introduction}

Korea has developed excessively for several decades in fashion field and is now one of the countries which have huge fashion industry. However, many barriers still existed to solve in order to produce the best fashion products. Moreover students meet very difficult situation to get their jobs after graduation with the recent world economic depression. It means that the role of the educational institute to produce the talented person wanted by the industry is very important.

This paper was supported by Sunchon National University Research Fund in 2008. 접수일: 2011년 10월 27일 심사일: 2011년 11월 1일 게재확정일: 2011년 12월 7일

Corresponding Author: Kim, Sun Hwa Tel: 82-61-750-3683 Fax: 82-61-750-3680

e-mail: shkim@sunchon.ac.kr 
According to Lee(2005), the number of students who graduated from universities, colleges, and institute related fashion field, were assumed around 12,000 every year. According to extension of fashion industry size in our country on 1990's, the department of fashion area was very popular and the number of students was rapidly increased. But the improvement of productivity due to low wages of late developing country such as China. Sign in WTO of China, 2008 Peking Olympic and 2010 Shanghai EXPO make textiles and fashion industries of our country wither considerably and most fashion institute be in big trouble(Lee 2005; Lee 2007) Actually, fashion academic institutes feel recently that there are limitations for them to produce a fitted person with the existing curriculum for the fashion industry changing rapidly. As a strategy to respond, Lee(2005) insisted that not only the changes of the professional education system in fashion but also characterization and differentiation by educational institutions were necessary. For examples, some National Universities change resolutely the name of the department from the Clothing and Textiles being stick for a long time to Fashion Design or Fashion Marketing, and some universities have changes their curricular practically.

The curriculum is a basic tool for the academic institution to produce the fitted person for the industry. First of all, we should grasp which ability is the most needed for the industry and which course is needed for the basis. So it is important to understand differences of the curricular between our country and other developed countries in order to know what our curricula are headed toward.

The study was focused on the curricular of universities only in this time because fashion academic institutions in Korea were too spread out through universities, colleges and technical institutes. Also the objective of the study was the comparison of the curricular between Korean and American Universities because the representative country which was teaching the fashion through the universities, was USA even though there were many other fashion developed countries such as France, Italy, Japan and so on.

\section{Theoretical Background}

According to $\mathrm{Ku}$ et al.(1999), Korea textile industry had served the role as a leader in exportled policies for Korean economy but since the 1990's, textile and garment export slipped price competition in the late developing and quality competition in developed countries in major export industries. Moreover the environment of domestic market has been much changed since IMF time, so up-market and low-cost products have been going the anode furnace. Also they insisted that our fashion industry has been keep as uniform laborintensive industry and has failed to meet the needs and the changes until now in spite of customized, diversification and segmentation of consumer needs due to globalization and internet information, however it should be changed to small quantity batch system to satiate consumer's emotions and needs, especially further to industry focused on emotion such as 'production of a variety' in the future. That is, it should be changed to technology and knowledgeintensive industry focusing on value-added product development, planning and marketing through the specialization and segmentation. Therefore, fashion education institutes which has a pivotal role in training student to be able to adapt quickly to such changes, should always cognize social and industrial changes and can predict how the changes affect to fashion industry, so should be sought development of new directions consistently and actively(Lee et al. 1993).

A few studies about the curriculum have mainly done on 1990's(Do et al. 1994; Lee et al. 1993; Shin 1995). Ku et al.(1999) did comparative study among Korea, USA, UK, Japan and Hong Kong on 
1999, but focused on marketing area with emphasis on production and distribute process flow of fashion industry. Since 2000, comparative study to USA or Japan in fashion marketing area(Lee 2002; Lee 2003; Lee 2003; Lee \& Park 2007) have been done mainly. This means that development of fashion industry make the study focus on fashion marketing area. However, Lee(2005) insisted that reorganization of the department which can be in respond to demand necessary to, such as not only fashion marketing and distribution area but also textile, textile design and pattern design, should be necessary. Do et al.(1994) has discovered that there were differences of the curricular according to the name of department, that is, textile science classes were most highly opened as $29 \%$ in the department of Clothing or Clothing \& Textiles and on the other hand, costume design area were opened 33\% and clothing construction areas were $27 \%$ in cased of the department of Fashion, Clothing Design or Fashion Design relatively.

\section{Methodology}

Curricular and related information of Korean universities were collected through the internet, telephone calls and e-mails from March to May, 2006 at first and modified the changes for the time being on August, 2009. Four private departments from 92 departments were examined only names of the departments because the curricula couldn't be gotten from those. So those were treated as missing data and opened total subjects credits and subject credits for each sub-field were examined from the other 88 departments. Those of American universities listed on the directory of ITAA(International Textile and Apparel Association), were also collected through the internet only from January to March, 2009.

Lee et al.(1993) classified sub-fields of fashion area as clothing science, clothing construction, costume history, clothing socio-psychology and costume design. Hong \& Scheurell(1997) classified those as textile, clothing management, clothing hygiene, costume history, clothing construction, costume design, costume aesthetics, clothing socio-psychology, fashion marketing. However, sub-fields in this study were classified seven fields such as construction, design and aesthetics, textile, socio-psychology, history, marketing, and environmental area resulted from kinds of classes which were opened.

First of all, to grasp the name of the department is very important because it expresses the ultimate goal what it aims for and decide finally the direction of the curricula. Therefore, names of all departments including total credit opened, credits opened for each area and so on between two countries, were analyzed using the descriptive statistics.

\section{Results and Discussion}

\section{Numbers of Universities which has Fashion Field in Korea and USA}

There were 20 national universities including one municipal university and 61 private universities with fashion related departments in Korea, while 87 public universities and 21 private universities in USA(Fig. 1).

Ninety two departments were existed at 81 universities in Korea, which 21 departments were from 20 national universities and 71 departments from 61 private universities. Eight private and one national universities had two majors, and a private university had three majors in the fashion field in Korea. On the other hand, Three public universities and one private university had two different majors or departments offering such a degree resulting in 90 programs at public universities and 22 programs at private universities. Four private departments of these 92 were examined only names of the departments because the curricula couldn't be gotten from those. So those were treated as missing data, and opened total credits and credits for each sub-fields were 
examined from the other 88 departments.

Three public universities and one private university had two different majors or departments offering such a degree resulting in 90 programs at public universities and 22 programs at private universities.

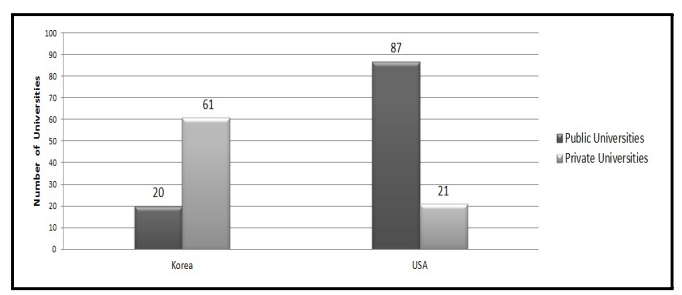

Fig. 1. Numbers of public and private universities opened department of fashion area between Korea and USA

Private universities opened fashion related departments three times more than the Public universities in Korea, but public universities opened four times more than the private universities in USA. also public universities in USA opened fashion program relatively four times more than those in Korea, but private universities in Korea opened fashion program three times more than those in USA. This means that USA think more important than Korea fashion education as the public education.

\section{Name of Department in Fashion Field}

Names of the departments were expressed variously. They could be grouped in six areas such as 'Fashion Design', 'Clothing \& textiles', 'Fashion
Marketing', 'Fashion Design \& Marketing', 'Textile Design' and others. Others included the following departments; Play Costume Design, Fashion Stylist, Traditional costume, Traditional Fashion and Culture, and Fashion beauty Design and so on.

'Clothing and Textiles' and 'Fashion Design' in name of the departments were most as 28 and 40 universities in Korea(Fig. 2). Especially, twelve national universities(57\%) were named 'Clothing \& Textiles' compared to four national universities (20\%) named to 'Fashion Design'(Table 1). But thirty six private universities $(51 \%)$ were named as 'Fashion design' compared to sixteen private universities(23\%) were named as 'Clothing \& Textiles'(Table 1). This means that national universities usually pursue theoretical learning, but private universities aim to practical learning in Korea. Some universities had their unique name such as 'Fashion Style', 'Total Fashion Design', 'Traditional Fashion Design' and so on in Korea.

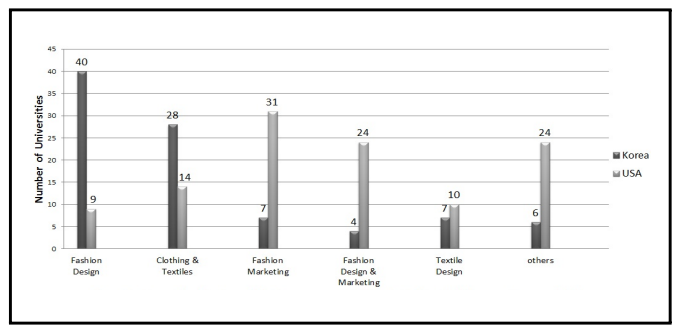

Fig. 2. Name classifications of the departments or majors in fashion field between Korea and USA

Table 1. Name classifications of departments or majors in fashion field between Korea and USA

\begin{tabular}{|c|c|c|c|c|c|c|c|c|c|c|c|c|c|c|}
\hline & & \multicolumn{2}{|c|}{$\begin{array}{l}\text { Fashion } \\
\text { design }\end{array}$} & \multicolumn{2}{|c|}{$\begin{array}{c}\text { Clothing \& } \\
\text { textiles }\end{array}$} & \multicolumn{2}{|c|}{$\begin{array}{c}\text { Fashion } \\
\text { marketing }\end{array}$} & \multicolumn{2}{|c|}{$\begin{array}{l}\text { Fashion D. \& } \\
\text { marketing }\end{array}$} & \multicolumn{2}{|c|}{$\begin{array}{l}\text { Textile } \\
\text { design }\end{array}$} & \multicolumn{2}{|c|}{ Others } & \multirow{2}{*}{$\begin{array}{c}\text { Total } \\
\mathrm{n}\end{array}$} \\
\hline & & $\mathrm{n}$ & $\%$ & $\mathrm{n}$ & $\%$ & $\mathrm{n}$ & $\%$ & $\mathrm{n}$ & $\%$ & $\mathrm{n}$ & $\%$ & $\mathrm{n}$ & $\%$ & \\
\hline \multirow{2}{*}{ Korea } & national u. & 4 & 19 & 12 & 57 & 3 & 14 & 1 & 5 & 1 & 5 & 0 & 0 & 21 \\
\hline & private $\mathrm{u}$. & 36 & 51 & 16 & 23 & 4 & 6 & 3 & 4 & 6 & 8 & 6 & 8 & 71 \\
\hline \multirow{2}{*}{ USA } & public u. & 7 & 8 & 13 & 33 & 25 & 28 & 20 & 22 & 9 & 10 & 16 & 18 & 90 \\
\hline & private $\mathrm{u}$. & 2 & 9 & 1 & 5 & 6 & 27 & 4 & 18 & 1 & 5 & 8 & 36 & 22 \\
\hline
\end{tabular}


On the contrary, 'Fashion Marketing' were most dominant as 31 universities which were 25 public (28\%) and 6 private(27\%) universities, and 'Fashion Design and Marketing' were the second as 24 universities which were 20 public(22\%) and 4 private(18\%) universities in USA(Fig. 2 \& Table 1). This means that both public and private universities aimed to marketing area as the first important field in USA. Twenty four universities in USA had unique name such as Korea(Fig. 2).

\section{Total Credits Opened}

Ninety percent of the universities in Korea opened over eighty total credits and most universities opened from 81 to 110 total credits, but $83 \%$ of Amercian universities opened under the 90 total credits and 34 universities opened 50 and under total credits(Fig. 3). This means that education in undergraduate of USA is focused on more liberal education than major education as it knows.

Thirteen departments opened over 120 credits, and 9 departments under 80 credits in Korea. Also the majority of national universities opened from 81 to 120 credits and eleven private departments opened over 120 subject credits in Korea. the national department opened the least was 72 credits and the private department was 63 credits in Korea.

Twenty six public(29\%) and eight private(36\%) universities in USA offered less than 50 credits and 10 public(11\%) and 3 private(14\%) universities in USA offered more than 100 credits(Table 2). Rest of universities in USA varied widely in the number of credits offered in fashion courses.

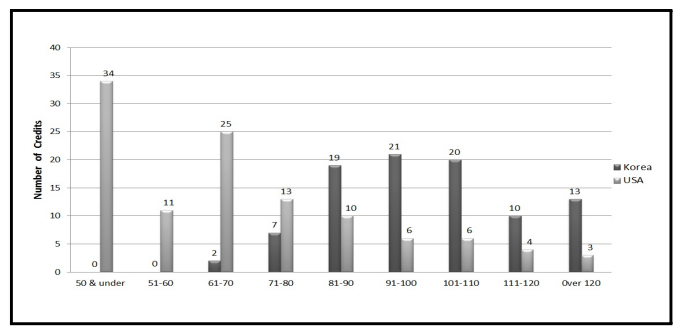

Fig. 3. The comparison of total credits between Korean and American universities

\section{Specific Areas opened and its Credits}

Most universities in Korea opened many credits for most area of fashion field more than those in USA except marketing and socio-psychology area. Also credits in design /aesthetics opened most in Korean universities, but credits in marketing opened most in USA(Fig. 4). This is equivalent as result of the name of department opened in university. It means that Korean universities opened relatively many credits in construction, design/aesthetics and textile area related that the name of department were mostly 'Clothing \& Textile' and 'Fashion Design'. American universities which have mainly the name of 'Marketing' as the department, opened relatively many credits in marketing area.

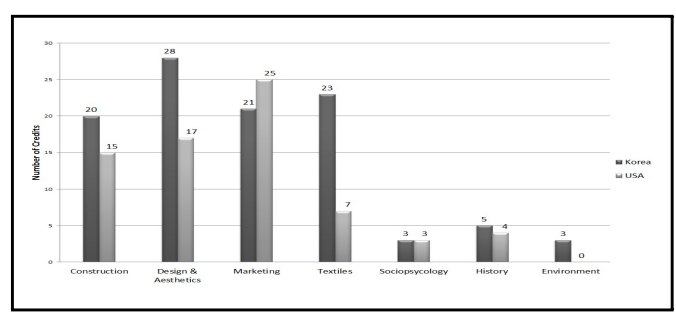

Fig. 4. Average credits opened for sub-fields between Korea and USA

Table 2. Total credits opened at the department of fashion field between Korean and American universities

\begin{tabular}{|c|c|c|c|c|c|c|c|c|c|c|c|}
\hline & of credits & $50 \&$ under & $51-60$ & $61-70$ & $71-80$ & $81-90$ & $91-100$ & $101-110$ & $111-120$ & over 120 & Total \\
\hline \multirow{2}{*}{ Korea } & national $\mathrm{u}$. & 0 & 0 & 0 & 2 & 4 & 4 & 5 & 4 & 2 & 21 \\
\hline & private $\mathrm{u}$. & 0 & 0 & 2 & 5 & 15 & 15 & 13 & 6 & 11 & 67 \\
\hline \multirow{2}{*}{ USA } & public u. & 26 & 8 & 24 & 11 & 7 & 4 & 4 & 3 & 3 & 90 \\
\hline & private $\mathrm{u}$. & 8 & 3 & 1 & 2 & 3 & 2 & 2 & 1 & 0 & 22 \\
\hline
\end{tabular}




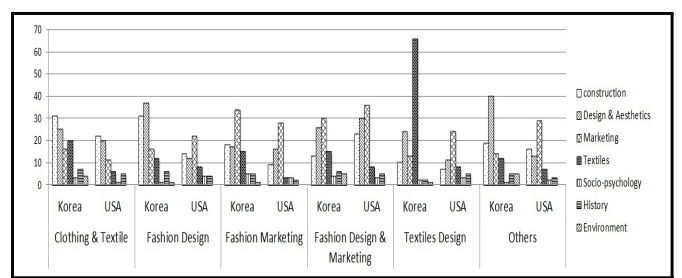

Fig. 5. Average credits opened for sub-fields according to the name of the department between Korea and USA

In Korea, opened credits in each sub-fields indicated a certain tendency according to the name of department, that is, credits in construction and design/aesthetics area opened mainly than in other fields for the department of clothing and textiles, or credits in marketing area opened more than in other fields for the department of fashion marketing(Fig. 5). However, there was no consistency between opened credits in sub-fields and the name of department in USA except marketing area. For example, majors in Fashion Design, Textile Design and Others in USA opened more credits in marketing area relatively than other sub-fields. Also there were no classes in environment area at the universities in USA, even though one to five credits opened in the sub-field in Korea.

\section{Conclusion}

Even though the name of 'Clothing \& Textile' has a long history of association with what was formerly called home economics, there were many changes for the name of department in fashion area recently, but many universities still remained 'Clothing and Textiles' as academic situation. However, many students who learn in fashion field get jobs at companies related to fashion area not at the universities every year. So courses offered in the fashion design area should helped students to get the specific knowledge, aptitudes, and skills for working at the company and students want to acquire practical knowledge for fashion field from universities. Except marketing area, Korean students learn more knowledge in other fashion sub-fields than American students. Also they took more classes than American students relatively. Therefore, even though the students in USA learn more marketing courses than those in Korea, the difference is not many especially if compared to the differences of other sub-fields. This means that Korean students were more skillful than American students for making garments, except marketing area. That is, we need to educate professional in marketing and distribution area to make students be more skillful in marketing area compared to other fields.

This Study was examined for only 4 years universities but the curricular of not only 4 years universities but also 2 years professional colleges and fashion institutes will be necessary to be examined and compared among them, too in the future.

\section{References}

Ku YS, Kim JW, Park K, Park K, Choo TG(1999) Analysis of Fashion Curriculum in 4-year Colleges: Cross-national Comparison of Korea, USA, UK, Japan \& Hong Kong. J of the Korea Home Economics Association 37(11), 19-32.

Do KH, Choi KS, Lee JO, Cho C(1994) A Study on the Fashion Specialized Education for the Development of Fashion Industry. The Korean Society of Costume 23, 225-248.

Hong KH, Scheurell DM(1997) The Development Process of Fashion Products. Textile Techniques and Industry 1(4), 481-487.

Lee HY, Lee JH, Chung KY(1993) The study on the University Curricular in Fashion Field. Natural Science (Daejeon Univ) 4(1), 117-132.

Lee HJ(2005) Upbringing Scheme of Fashion Experts for the Corresponding Globalization of Fashion Industry. J of Korean Society of Clothing Industry 7(5), 463-466.

Lee HJ(2007) Upbringing Scheme of Fashion Currency Specialists According to Development of Currency Industry. J of Korean Society of Clothing Industry 9(6), 577-580. 
Lee SH, Park SK(2007) A Globalization-Focused Human Resource Development Program in Fashion Marketing Area-Comparison of Korean and U.S. Graduate School's Fashion Marketing Curricula-. J of the Korean Society of Clothing and Textiles 31(3), 420-432.

Lee $\mathrm{YJ}(2002)$ A Comparative Analysis of Fashion Marketing Education between Korea and USA (Part I). J of the Korean Society of Clothing and Textiles 26(5), 727-736.

Lee YJ(2003) A Comparative Analysis of Fashion Marketing Education between Korea and USA (Part II). J of the Korean Society of Clothing and Textiles 27(2), 169-176.
Lee YJ(2003) A Comparative Analysis of Fashion Marketing Education between Korea and Japan. J1 of the Korean Society of Clothing and Textiles 27(6), 725-734.

Shin SM(1995) A Study on the Assessment of Current and Future Directions for Clothing and Textiles. $\mathbf{J}$ of the Korean Home Economics Association 33(6), 187-198. 